\title{
EXPECTATIONS AND EXPERIENCES OF INDONESIAN TEACHERS WHO HAVE, AND HAVE NOT, DONE EXTENSIVE READING
}

\author{
Rob Waring ${ }^{a}$, Nida Husna ${ }^{b}$ \\ ( ${ }^{a}$ waring.rob@gmail.com) \\ Notre Dame Seishin University \\ 2-16-9 Ifuku-cho, Kita-Ku, Okayama, Japan \\ ('nida.husna@uinjkt.ac.id) \\ Syarif Hidayatullah State Islamic University \\ Jl. Ir. H. Juanda No. 95, Ciputat 15412, Indonesia
}

\begin{abstract}
Extensive Reading (ER) in Indonesia is in its infancy. Over the past 2-3 years a small band of ER enthusiasts led by the Indonesian Extensive Reading Association (IERA) and the Extensive Reading Foundation (ERF) have started promoting ER in the archipelago. In July 2018, IERA and the ERF conducted all-day ER workshops to over 1000 teachers in six locations. The post-workshop questionnaire reported here shows that these workshops were successful in getting most of the teachers to the Introduction Stage of ER acceptance. The talks were also helpful in changing the teachers' attitudes and beliefs about ER, as well as in helping the IERA staff to understand what challenges lie ahead for the promotion of ER. The questionnaire also revealed that after attending the workshops many teachers feel frustrated they cannot implement ER due to a lack of specific knowledge about how to set up and manage the ER program in their own situation, or due to institutional resistance, misunderstandings and inertia stemming from a satisfaction with the current paradigm. The questionnaire points to the need for a second folow-up series of workshops or other training, to deepen the participants' knowledge to give them enough support to move to the Implemention Stage of ER.
\end{abstract}

Keywords: extensive reading, Indonesia, IERA workshops

DOI: http://dx.doi.org/10.15639/teflinjournal.v30i2/153-170 
Extensive Reading (ER) is booming all over Asia. In the past 20 years, thousands of institutions have adopted the ER approach and ER Associations have been set up in Japan, Korea, Taiwan, China and elsewhere under the auspices of the Extensive Reading Foundation (www.erfoundation.org). In some of these areas, ER is well-established and is widely as is needed, and is to a large extent understood and accepted as a valuable part of the EFL curriulum even if it is not practiced.

The ERF's involvement in developing ER in Asia has revealed several stages on the road to an acceptance of ER either in an institution, or a community. At the Introduction Stage, where the community is new to ER, there could be any of several reactions to a workshop on ER. These might range from, at one end, an initial elation that the missing piece of the EFL puzzle has been found, or, at the other, there might be resistance to a new paradigm because the current practice seems to be working just fine and ER is perceived as unnecessary, often by the students' parents or the students themselves. There may even be open hostility, especially from entrenched supporters of the current paradigm (e.g. Faisal \& Schmitt, 2009). At this stage, the training conducted in ER workshops and lectures can only expect to raise awareness of the importance of ER, to open eyes and minds, and hopefully attract the hearts of a few people who will lead the way forward by starting a pilot ER program of their own. Training usually results in many teachers accepting ER as important but they do not feel it is part of their own personal responsibility or classroom duties as ER is seen as an outsider or 'other'. Or they feel that there are too many challenges to actually start. Nevertheless, a few individuals start ER programs, gather data and report this to colleagues showing how easy and how beneficial ER can be.

The second Implementation Stage occurs when teachers can no longer ignore ER because it has become part of the conversation surrounding discussions of EFL, or maybe a school or district orders the implemention of ER upon the staff with which they must now engage to some extent. This might bring resistance, or elation as well. In general, after successful training and some hands-on experience, few teachers resist ER strongly, especially when pilot studies show its benefits not only to the students but to the curriculum as a whole. It is at this detailed stage training is most effective because it can be directly related to some initial experience or knowledge the participants aleady have. The training should involve the practical sides of ER by introducing many ways and variants of how to introduce, monitor, facilitate, conduct and 
assess ER classes and introduce it to their students successfully. The aim would be to deepen understanding allowing teachers to align their practice to their students' needs. At this stage, some teachers emerge to become 'local gurus' serving not only their own community by writing articles, or conducting careful research, but even by giving their own lectures and workshops. The third Integration Stage is when the whole school or district has implemented ER fully into the curriculum, and the administration, students, parents and teaching staff are all committed to it. The ER has targets, goals, and outcomes, and is fully funded and valued by all.

\section{What is ER?}

Although millions of students are now reading extensively throughout Asia, ER is still unknown and unpracticed in many areas. Some teachers and students have not even reached the Introduction Stage. Part of the reason is that teachers have not heard of ER, or do not know how to implement it, or they may not have the resources, class time or even materials to do ER. Other teachers may not do ER because it does not fit with what they feel is appropriate for the EFL classroom (e.g. Faisal \& Schmitt, 2009). There are tens of thousands of teachers throughout Asia who might resist ER because they believe a teacher's role is to stand at the front of class and teach, then test, and then teach some more using a course book. Because of these reasons, there are millions of students lacking access to books such as graded readers that they can read easily in order to develop their natural reading ability in English.

Typically, an ER program would require students to read tens of thousands (and sometimes hundreds of thousands) of words each semester of easy graded readers that they can read fluently and enjoyably without needing a dictionary. A core principle of ER is to get the students to read as naturally and as fluently as possible at their own level of proficiency. This is often contrasted with intensive reading which is typically done using a reading course book with short difficult passages followed by comprehension questions and language work activities. The aim of these two approaches to reading is different. ER is about building speed, fluency and enjoyment through reading massive amounts of text. Intensive reading (or 'study reading') is done to learn new words, grammar and language strategies which will later be applied to real texts. 


\section{Extensive Reading in Indonesia}

ER is not well-understood in Indonesia - yet. It is roughly at the same stage Japan and Korea were some 10-15 years ago. But this can change rapidly as it has in Vietnam in the past two years. There are many reasons why it is not easy to set up and run an extensive reading program in formal Indonesian classrooms. One of the reasons is that ER requires the teachers to think beyond the ordinary language-focused, teacher-controlled classroom which prepares students for high-stake exams. In this environment, adding ER into the curriculum and make reading a habitual part of the curriculum, will require considerable effort because the curriculum is often designed centrally and with few opportunities for the teachers to change it. Even though some students have a positive attitude toward reading, they typically only read school materials rather than read for pleasure (Iftanti, 2012). However, since many studies have shown that an ER program significantly influences the students' acquisition of English, many Indonesian teachers are starting to include ER as part of their English teaching further demonstrating that an ER program can be adopted in Indonesian classrooms.

For example, Damayanti's (2017) study focused on the improvement of students' English narrative writing after having read extensively and developed the students' English oral competences and improved their narrative text writing. The study shows that by having to retell the story from their book helped the students to create better narrative writing and develop their ideas about what to write.

Extensive reading has also been proven to be effective in improving students' learning styles especially in writing competency (Umar \& Artini, 2013). Zacharias (2017) showed ER can help meet efficiency and effectiveness goals as well. To do this, students may need different types of approach in doing the activity in the ER program. Therefore, understanding their needs and ascertaining whether the curriculum will allow these activities should be part of the planning of the program in order to increase the students' motivation (Day \& Bamford, 2002).

A combination of activities in the ER program, such as Guided Extensive Reading, would also maximize the benefit of the program for the students (Lestari \& Yusra, 2014). They could choose the reading materials based on the teacher's suggestion, or their own, or what they need. When the students experience the benefits of reading extensively, it builds a positive attitude 
toward the reading program and to the reading itself (Anggraini, 2018). There is a risk of reading anxiety when students do something new. However, understanding how the program works can significantly influence their foreign language skills, so the students strongly suggested that the program should be continued and become compulsory (Anggraini, 2018; Husna, 2017). The most obvious benefit from the program was the vocabulary acquisition (Cahyono \& Widiati, 2006; Wijaya, 2018).

In 2016, the Indonesian Extensive Reading Association (www.ieraindonesia.id) was established at Sanata Dharma University in Yogyakarta to promote ER, assist schools and teachers to understand ER, and help them to adopt ER in their classes, find resources and manage their ER programs and to find out more about extensive reading. As part of this mission, in July 2018, several speakers from IERA and the Extensive Reading Foundation conducted a lecture tour of Western Java giving full-day ER workshops to about 1,000 teachers at six locations. The aim of these talks was to not only raise awareness of ER, but to show teachers how it might be done. By interacting with so many teachers in this way, IERA was able to better understand what teachers in Indonesia believe about ER and clarify what Indonesian teachers think about ER. After these talks, the participants were encouraged to join the IERA Facebook group to learn about ER. This provided a vehicle for IERA to survey the teachers after the workshops to find out what they learnt and how effective the ER workshops were, and what they believed about ER and to ascertain if there are differences between those who have, and those who have not, done ER.

The question remains however, what the teachers do, in fact, know about ER itself. Moreover, we need to find out why it is that some teachers readily accept ER, while others resist. What is it that prevents them from adopting ER? Is it resource issues, a lack of training, a misunderstanding of ER, or something else? Do they know how to set up and manage a library and how to select the most appropriate materials for their students? An online questionnaire was given to Indonesian teachers who had attended the IERA and ERF workshops to ascertain their current understanding.

\section{Research Questions}

1. What are the attitudes and beliefs of Indonesian teachers about ER?

2. Do they differ depending on whether the teacher has done ER, or not? 
158 TEFLIN Journal, Volume 30, Number 2, July 2019

\section{METHOD}

\section{Subjects}

Data were gathered from subjects already familiar with the concept of ER and reflect that. Not all of their knowledge about ER would have come from the workshops, but this questionaire would only have been meaningful if it attracted people interested in ER. As we saw from the data, about $90 \%$ of the subjects have not done ER, or had done it only a little, so their knowledge was probably very elementary.

The subjects were 34 Indonesian teachers mostly from Java. They work in a variety of teaching environments including universities (15), high schools (9), middle schools (8), elementary schools or kindergarten (3). Very few of them have experienced extensive reading as a student, 9 have taught extensive reading as part of, or as a whole class; and 4 have never done extensive reading.

\section{Questionnaire Design}

The questionnaire is based on one reported in Waring and Chu (2017) and has several sections. This survey compared responses from teachers who have little or no experience of ER, those with a modest amount and those who might be called 'experienced'. The aim was to compare these groups to see if there are any similar or differing beliefs and concerns about setting up and running an ER program.

\section{Procedure}

The questionnaire was developed and piloted in Google Forms. The url for the questionnaire (https://goo.gl/forms/jaRBRXX5DN9D2SaN2) was sent to personal contacts and distributed widely on social media such as the IERA Facebook page and was responded to mostly by those who had attended the IERA workshops. Readers are encouraged to take the questionnaire for themselves to add reliability and feedback for IERA. The subjects were given unlimited time to answer the questionnaire. The results were downloaded and tabulated in Microsoft Excel. The data were then analysed and are presented in the next section of the paper. 
Waring \& Husna, A Report From the IERA Workshops 159

\section{FINDINGS AND DISCUSSION}

\section{Findings}

First we will look at the results for the ways the subjects suggested ER should be integrated into the curriculum. Then we will look at what difficulties they face and finally whether they understand the concept of ER. Tables 1 and 2 distinguish between those who are "quite experienced" with ER $(n=4)$, those with a "little experience" $(n=24)$ and those with "No experience" $(n=4)$. Two subjects did not report their level of involvement with ER. Tables 3 and 4 combine the data from all participants.

Table 1. Thoughts on Integrating Extensive Reading into a School's Curriculum

\begin{tabular}{|c|c|c|c|c|c|c|c|c|c|c|c|c|c|c|c|}
\hline & \multicolumn{5}{|c|}{ No experience $(n=4)$} & \multicolumn{5}{|c|}{ Little experience $(n=24)$} & \multicolumn{5}{|c|}{$\begin{array}{l}\text { Quite experienced } \\
\qquad(\mathrm{N}=4)\end{array}$} \\
\hline & SA & A & $\mathrm{N}$ & $\mathrm{D}$ & SD & SA & A & $\mathrm{N}$ & $\mathrm{D}$ & SD & SA & A & $\mathrm{N}$ & $\mathrm{D}$ & SD \\
\hline & \multicolumn{5}{|c|}{$\%$} & \multicolumn{5}{|c|}{$\%$} & \multicolumn{5}{|c|}{$\%$} \\
\hline $\begin{array}{l}\text { Schools are not } \\
\text { willing to change } \\
\text { the curriculum to } \\
\text { accommodate } \\
\text { Extensive } \\
\text { Reading. }\end{array}$ & 0 & 100 & 0 & 0 & 0 & 20 & 52 & 12 & 12 & 4 & 0 & 75 & 0 & 25 & 0 \\
\hline $\begin{array}{l}\text { Schools find it } \\
\text { hard to choose } \\
\text { which Graded } \\
\text { Readers to buy. }\end{array}$ & 0 & 75 & 25 & 0 & 0 & 12 & 44 & 12 & 28 & 4 & 0 & 75 & 0 & 25 & 0 \\
\hline $\begin{array}{l}\text { Teachers do not } \\
\text { understand what } \\
\text { Extensive } \\
\text { Reading is and } \\
\text { why it is } \\
\text { necessary for } \\
\text { language } \\
\text { learning. }\end{array}$ & 0 & 75 & 25 & 0 & 0 & 16 & 40 & 16 & 24 & 4 & 0 & 75 & 0 & 25 & 0 \\
\hline $\begin{array}{l}\text { Teachers are not } \\
\text { willing to get } \\
\text { involved in the }\end{array}$ & 25 & 50 & 0 & 0 & 25 & 8 & 44 & 28 & 16 & 4 & 0 & 50 & 0 & 50 & 0 \\
\hline
\end{tabular}




\begin{tabular}{|c|c|c|c|c|c|c|c|c|c|c|c|c|c|c|c|}
\hline & \multicolumn{5}{|c|}{ No experience $(n=4)$} & \multicolumn{5}{|c|}{ Little experience $(n=24)$} & \multicolumn{5}{|c|}{$\begin{array}{l}\text { Quite experienced } \\
\quad(\mathbf{N}=4)\end{array}$} \\
\hline & SA & A & $\mathrm{N}$ & D & SD & SA & A & $\mathrm{N}$ & D & SD & SA & A & $\mathrm{N}$ & D & SD \\
\hline & \multicolumn{5}{|c|}{$\%$} & \multicolumn{5}{|c|}{$\%$} & \multicolumn{5}{|c|}{$\%$} \\
\hline $\begin{array}{l}\text { Extensive } \\
\text { Reading Program } \\
\text { because it will } \\
\text { create more work } \\
\text { for them. }\end{array}$ & & & & & & & & & & & & & & & \\
\hline $\begin{array}{l}\text { Teachers are not } \\
\text { well-trained for } \\
\text { Extensive } \\
\text { Reading. }\end{array}$ & 25 & 25 & 0 & 50 & 0 & 32 & 48 & 16 & 0 & 4 & 25 & 50 & 0 & 25 & 0 \\
\hline
\end{tabular}

The questions in Table 1 asked the subjects about their thoughts on integrating ER into a school's curiculum. The data reveal similar responses for the subjects with no, a little, or a lot of experience. Broadly, the subjects revealed that there is still a lack of a clear understanding of ER within Indonesia; that it is hard to find graded readers; and schools are mostly unwilling to change their curriculums to accommodate ER with only 3 subjects disagreeing with this and is most pronounced with teachers with little experience. Whether this opinion is because they have not tried ER, or whether their institution will not permit ER is not clear. But the data of the "little experienced' group suggest that they struggle to get ER accepted at their schools as they report 'strongly agree' with the four items preventing more widespread ER at school. There seem to be issues with knowing what graded readers to order and where to find them. Presumably this is because graded readers are published by foreign publishers who have a very small footprint in the EFL publishing market in Indonesia as a whole, so many teachers are not aware of what is available, or where to look.

The teachers also report that many of their colleagues do not understand ER sufficiently well to be willing to implement it. Moreover, even if they do, $100 \%$ of the 'No experience' group say there will be resistance at their school, but interestingly, those who have implemented ER report that while school resistance is still evident, in reality, some of the schools still resist. All groups report that there is insufficient training in ER in their schools. However, some 
of the more experienced teachers have had some success as they report less resistance, most likely because others in the schools have seen the benefits of ER.

The data in Table 2 below reveal that the vast majority of the subjects report a lack of understanding of ER in their teaching communities. They also report their students are not motivated to read extensively, and many do not read books even in their own language. There was also general agreement that the students do not know their own ability level well enough to choose graded readers appropriately. The teachers also reported a lack of funds and appropriate space for a library to host the reading collection. The teachers were also were concerned about how to build and manage the library stock in terms of leveling, cataloguing and labeling the books, and keeping a book record system. They were also worried the students might forget to return their precious books, presumably because the teachers may be concerned they will be held responsible if the books are lost. In terms of pedagogy, they were concerned whether they could find the time to do ER, and how to implement ER fairly across the curriculum when different classes would be doing different things especially in a test dominated environment.

Table 2. What do you think would be the challenges/difficulties of setting up an Extensive Reading Program in schools like, or similar to yours?

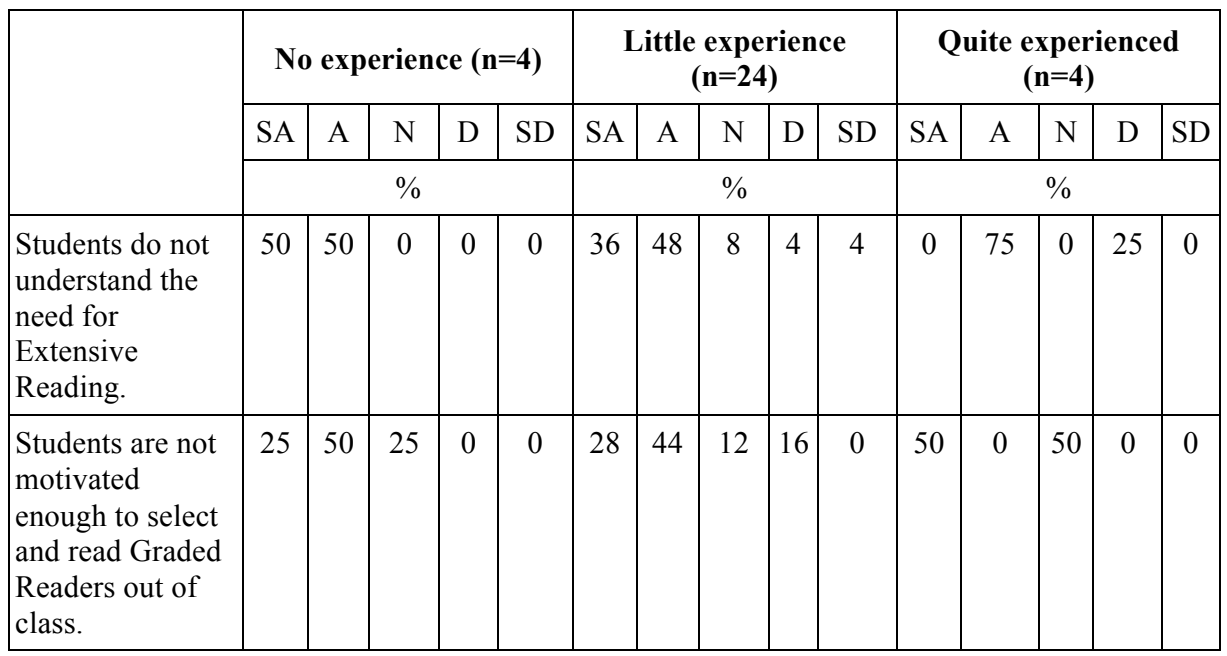


162 TEFLIN Journal, Volume 30, Number 2, July 2019

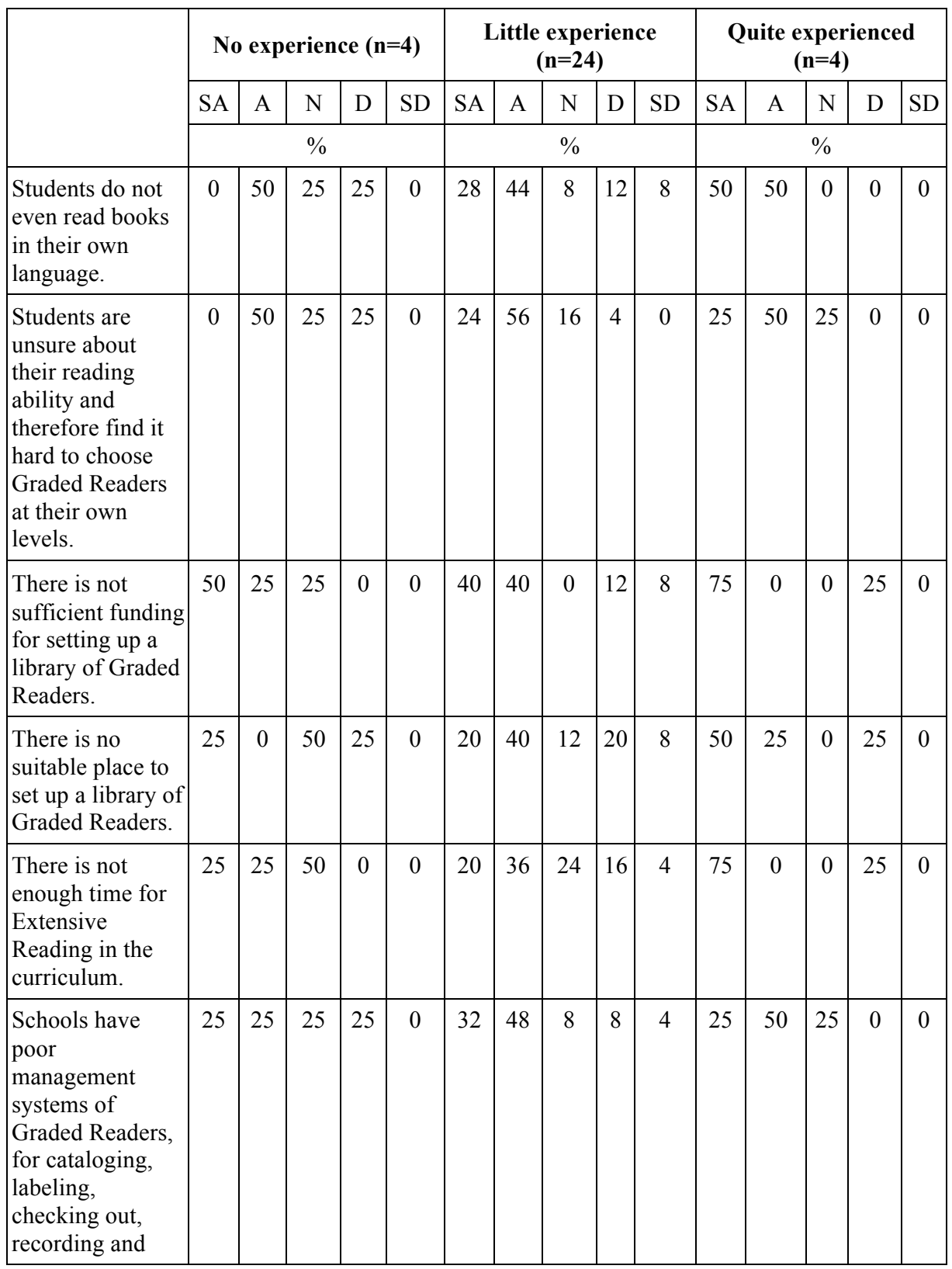


Waring \& Husna, A Report From the IERA Workshops 163

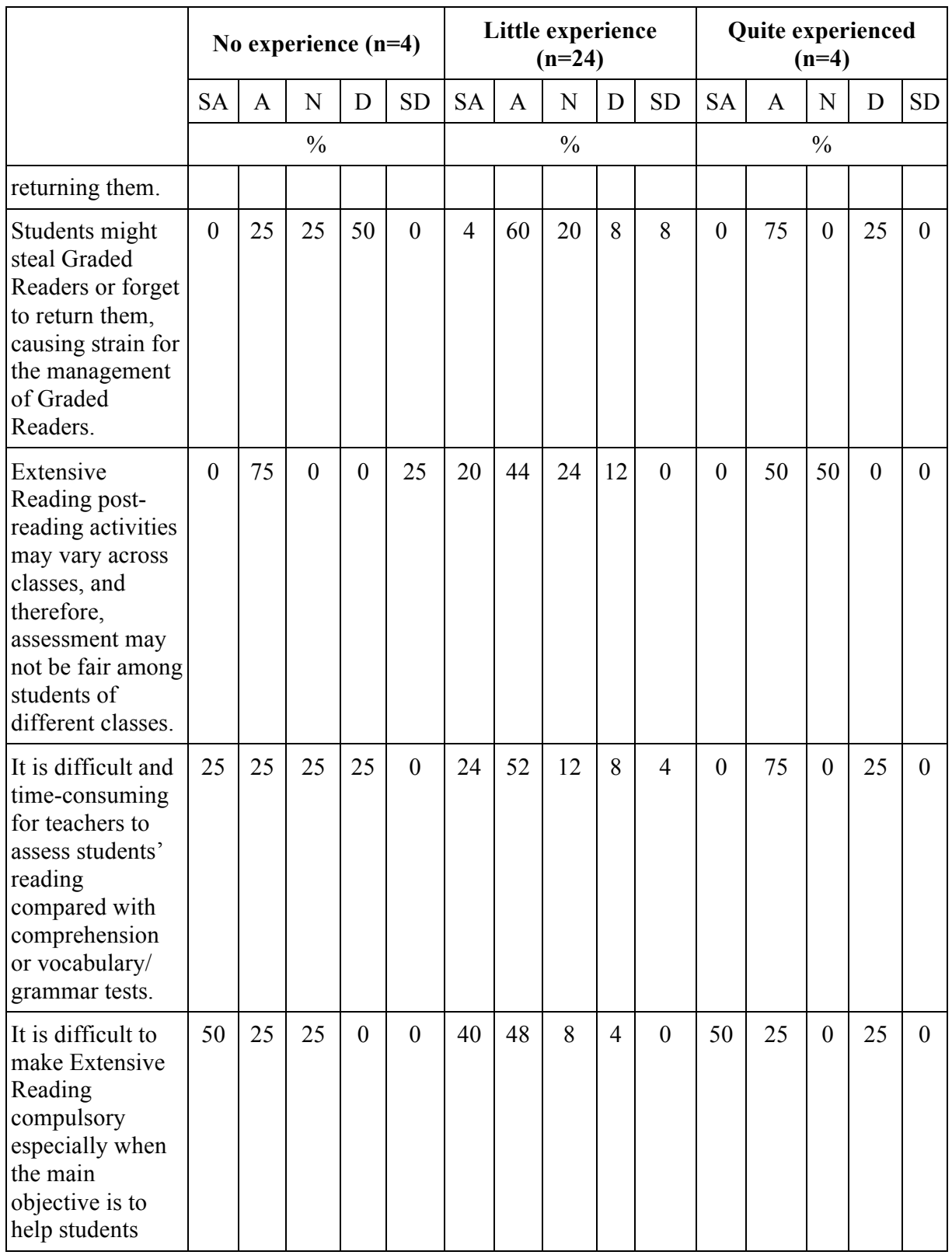


164 TEFLIN Journal, Volume 30, Number 2, July 2019

\begin{tabular}{|c|c|c|c|c|c|c|c|c|c|c|c|c|c|c|c|}
\hline & \multicolumn{5}{|c|}{ No experience $(n=4)$} & \multicolumn{5}{|c|}{$\begin{array}{l}\text { Little experience } \\
\qquad(n=24)\end{array}$} & \multicolumn{5}{|c|}{$\begin{array}{l}\text { Quite experienced } \\
\qquad(n=4)\end{array}$} \\
\hline & SA & A & $\mathrm{N}$ & $\mathrm{D}$ & SD & SA & A & $\mathrm{N}$ & $\mathrm{D}$ & SD & SA & A & $\mathrm{N}$ & $\mathrm{D}$ & SD \\
\hline & \multicolumn{5}{|c|}{$\%$} & \multicolumn{5}{|c|}{$\%$} & \multicolumn{5}{|c|}{$\%$} \\
\hline pass tests. & & & & & & & & & & & & & & & \\
\hline $\begin{array}{l}\text { It takes a long } \\
\text { time to evaluate } \\
\text { the success of an } \\
\text { Extensive } \\
\text { Reading Program }\end{array}$ & 50 & 50 & 0 & 0 & 0 & 28 & 60 & 8 & 0 & 4 & 25 & 50 & 0 & 25 & 0 \\
\hline
\end{tabular}

Table 3. Why Students Should Do Extensive Reading

\begin{tabular}{|c|c|c|}
\hline & No. & $\%$ \\
\hline ... recycle and consolidate the language learnt in textbooks. & 5 & $14.7 \%$ \\
\hline ... build their vocabulary & 25 & $73.5 \%$ \\
\hline $\begin{array}{l}\text {... read a text carefully so that they can understand the content } \\
\text { deeply. }\end{array}$ & 5 & $14.7 \%$ \\
\hline ... learn lots of new words and grammar. & 18 & $52.9 \%$ \\
\hline $\begin{array}{l}\text {.. learn new vocabulary and grammar points through the careful } \\
\text { analysis of the language of the text., }\end{array}$ & 1 & $2.9 \%$ \\
\hline $\begin{array}{l}\text {... become effective readers by going from the word-by-word } \\
\text { level to the idea-by-idea level of reading. }\end{array}$ & 15 & $44.1 \%$ \\
\hline ... improve reading speed and reading fluency. & 22 & $64.7 \%$ \\
\hline $\begin{array}{l}\text {.. learn new vocabulary and grammar points through the careful } \\
\text { analysis of the language of the text. }\end{array}$ & 5 & $14.7 \%$ \\
\hline $\begin{array}{l}\text {... develop a sense of the language by seeing how it flows in its } \\
\text { natural context time and time again }\end{array}$ & 16 & $47.1 \%$ \\
\hline ... build confidence, motivation, enjoyment and a love of reading. & 25 & $73.5 \%$ \\
\hline ... build a lifelong habit of reading and learning. & 27 & $79.4 \%$ \\
\hline
\end{tabular}

$N=34$

The data in Table 3 above show the subjects understood that the main function of ER is to build a lifelong habit of reading (79.4\%); that they should 
be reading to improve reading speed and fluency (64.7\%); and to build confidence and motivation (73.3\%). The teachers are far less certain about other features of ER such as whether doing ER helps recycle previously learnt language, and helps students to move to higher levels of reading from the word-by-word level where the students are focused on comprehending words, to a wider level where the unit of comprehension is phrases and sentences.

One worrying aspect is why the figures are not higher for some of the other items that reflect common aspects of ER, as many of the subjects had attended the ER workshops a few weeks earlier. Indeed, $52.9 \%$ of the subjects said a function of ER was to learn new vocabulary and grammar, which is more closely associated with Intensive reading. While it can be said that ER does help build vocabulary, we can presume the teachers are thinking of new words and vocabulary. However, they reject the idea that ER is about a careful reading and analysis of the text $(14.7 \%)$ which is a typical feature of intensive reading.

Table 4. The Teachers' Opinions about Extensive Reading Practice

\begin{tabular}{llc}
\hline & No. & \% \\
\hline Reading authentic materials & 6 & $17.6 \%$ \\
\hline Reading for pleasure & 25 & $73.5 \%$ \\
\hline Reading fluently without using a dictionary & 13 & $38.2 \%$ \\
\hline Reading and being able to understand 98\% of the content of the text & 3 & $8.8 \%$ \\
\hline Reading as fast as possible & 9 & $26.5 \%$ \\
\hline Reading to learn new language and vocabulary & 12 & $35.3 \%$ \\
\hline Reading a text in detail to get a deep understanding of its contents & 4 & $11.8 \%$ \\
\hline Reading and being able to understand 98\% of the content of the text & 11 & $32.4 \%$ \\
\hline Reading short and simple texts followed by discussion & 10 & $29.4 \%$ \\
\hline Reading followed by comprehension questions & 4 & $11.8 \%$ \\
\hline
\end{tabular}


166 TEFLIN Journal, Volume 30, Number 2, July 2019

\begin{tabular}{lll}
\hline & No. & $\%$ \\
\hline Reading while knowing 98\% of the language in the text & 5 & $14.7 \%$ \\
\hline Reading a lot & 20 & $58.8 \%$ \\
\hline Reading at readers' own pace and level; & 2 & $5.9 \%$ \\
\hline Reading can take place anytime and anywhere & 2 & $5.9 \%$ \\
\hline
\end{tabular}

$N=34$

The data in Table 4 show that the majority of the subjects understand that ER means Reading for pleasure (73.5\%) or Reading a lot $(58.8 \%)$. Other aspects typically associated with a standard description of ER were only checked by fewer than $50 \%$ of the subjects, such as Reading fluently without using a dictionary (38.2\%), Reading and being able to understand $98 \%$ of the content of the text $(8.8 \%)$. Quite a few subjects attributed elements of reading pedagogy to ER that would normally be considered Intensive reading such as Reading authentic materials (17.6\%) and Reading to learn new language and vocabulary $(35.5 \%)$. Probably the most concerning are the very low responses to the ideas that students should be reading at the readers' own pace and level $(5.9 \%)$ and reading can take place anytime and anywhere $(5.9 \%)$ which are hallmarks of most ER programs and pedagogy.

There seems to be a general feeling that reading something above one's level is suitable even without much comprehension. This may be an outcome of the subjects saying that reading for pleasure is the most important aspect of ER, or in other words, if the student is enjoying the book, then they should be allowed to continue reading it even if they do not understand so much. Alternatively, it might be that the materials the students are reading are not suitable, or the only materials available are too difficult. Typically in ER, students are asked to read something a little above their level not a long way above their level. Indeed, it is often said students doing ER should be reading not at $i+1$, but at $i$ minus 1 so they can read smothly and fluently and at a level they can build a sense of language. 
Waring \& Husna, A Report From the IERA Workshops 167

\section{Subject's comments}

In this section, the subjects were asked to freely write their opinions about ER.

The idea of ER really captivates me in spite of its challenges

I'm looking forward to seeing the result (of the survey) since I love to implement ER in my class as well

I wish $i$ have some people or institutions that can help me to implement ER activity for my students

I do really hope $i$ will be invited in a workshop/seminar/conference about extensive reading. I do really appreciate if it can happen

I think the students at any school have to be provoked in practicing ER not only in providing the books and motivation, but also the experiences of some figures who can change their views on ER

You all have positive contribution to the reading habit

Teachers should guide students reading skill

I really want to have some English story books to read, because there are not any

English story books in my village, we saw some online but we can't afford them

These comments show that the teachers have a strong interest in ER and a desire to know more about ER, but often are unsure of the practice, or do not know where to find suitable materials. Future ER lectures and workshops need to focus on serving these needs.

\section{Discussion}

While the data show that not everyone who had attended the IERA workshops actually understands ER deeply, in sum we could say that the attendees of the workshops have definitely grasped what ER is in general terms. During the workshops, the attendees were shown some graded readers and did a little ER of their own. Surprisingly, only a very few had heard of, or seen graded readers, prior to the workshops, but after having seen some and read a few, $98 \%$ of the attendees said they thought they would be good for their students and $97 \%$ said they would buy some if the money was available. These reactions to ER and graded readers mirror those found in Waring and Chu (2017) in Vietnam and are broadly similar to those in most South East Asia 
communities new to ER. As further evidence of the success of the workshops, membership of the IERA Facebook page (https://www.facebook.com/groups/ $497214607143627 /$ ) grew by over $200 \%$ in the weeks following the workshops and today has exceeded 1,000 members. The attendees still lack the detailed knowledge of how to set up libraries, negotiate with administration to set up libraries and actually get ER moving and probably feel a bit frustrated in not knowing how to move forward. This suggests they are ready for detailed explanations of how to implement ER and understand the need for local gurus to guide them on the way.

All this should not be surprising. As with any aspects of EFL, whether it be ER, speaking, teaching writing and so on, we should not expect an audience to understand something that requires a shift in mindset (from more traditional methods and behaviours), as well as understand the myriad ways ER can be implemented in a single full-day workshop. (Waring \& Chu, 2017). The basis of ER is rather simple to understand as it just requires students to read a lot of easy books for enjoyment. However, the devil is in the details of implementation - with or without follow-up; how to manage a library; how to fit it into the curriculum; how to assess ER and fine-tune it to a specific institution or class, and so on. To fully understand these means learning more about ER and engaging with it in a practical sense to find out what works and what does not which implies more training and workshops are needed (Nation \& Waring, forthcoming).

In Tables 1 and 2, many of the subjects report a lack of understanding of ER in their teaching communities. However, some of these same teachers themselves seem not to understand ER deeply (Tables 3 and 4), whereas others do. Moreover, the data in Table 2 reveal that students in Indonesia do not really understand the need for ER. This is not really surprising given that the awareness of ER in practice is still very low in Indonesia. Indeed, only 4 of the 32 subjects (all teachers) of this questionnaire have done ER even though the call for responses to the questionnaire was put out on the ER in Indonesia Facebook page and by emailing others already interested in ER. This therefore means that because the data were gathered from subjects at least somewhat familiar with ER, the results should not be taken as representative of Indonesia as a whole. It can therefore be assumed that the awareness of ER programs in Indonesia would be much lower in communities not connected with ER. How much lower, we can only assume and should be the subject of a follow-up study. 
Waring \& Husna, A Report From the IERA Workshops 169

\section{CONCLUSIONS}

The data here paint a rather challenging but hopeful environment for ER practitioners in Indonesia. These workshops certainly raised awareness and interest but knowledge is still incomplete for many and implies the need for further training and experience. Until recently, ER in Indonesia has been in its infancy, or has not been well accepted, understood or practiced but the data here show this is beginning to change.

\section{REFERENCES}

Anggraini, R. D. (2018). Developing reading attuitude through extensive reading in EFL context. Proceedings of the Learning English in Modern Era, 6th Undergraduate Conference on ELT, Linguistics and Literature, 40-51. Yogyakarta: Sanata Dharma University Press,.

Cahyono, B. Y., \& Widiati, U. (2006). The teaching of EFL reading in the Indonesian context: The state of the art. TEFLIN Journal, 17(1), 36-58.

Damayanti, I. L. (2017). From storytelling to story writing: The implementation of reading to learn (R2L) pedagogy to teach English as a foreign language in Indonesia. Indonesian Journal of Applied Linguistics, $6(2), 229-242$.

Day, R., \& Bamford, J. (2002). Top ten principles for teaching extensive reading. Reading in a Foreign Language, 14(2), 136-141.

Faisal, A., \& Schmitt, N. (2009). Extensive reading in a challenging environment: A comparison of extensive and intensive reading approaches in Saudi Arabia. Language Teaching Research, 13(4), 383-401.

Husna, N. (2017). Practicing critical thinking through extensive reading activities. In A. G Abdullah, I. Hamidah, S. Aisyah, A. A Danuwijaya, G. Yuliani, \& H. S Munawaroh (Eds.), Ideas for 21st century education (pp. 3-8). London: CRC/Belkema, Taylor \& Francis Group.

Iftanti, E. (2012). A survey of the English reading habits of EFL students in Indonesia. TEFLIN Journal, 23(2), 149-164.

Lestari, Y. B., \& Yusra, K. (2014). Investing academic speaking through guided extensive reading: A case study in extensive reading class at English Department Mataram University Indonesia. Proceedings of the $61^{\text {st }}$ TEFLIN International Conference, 412-415. Solo: UNS. 
Nation, P. \& R. Waring. (forthcoming). Teaching extensive reading in another language. London: Routledge.

Umar, K. S., \& Artini, L. P. (2013). The effect of extensive reading and learning style on academic writing competency of semester five students of STKIP Hamzan Wadi Selong. e-Journal Program Pascasarjana Universitas Pendidikan Ganesha, 1, 1-13.

Waring, R., \& Van-Anh, Chu. (2017, August). Setting up and managing an ER program in Vietnam. Paper presented at the Fourth World Congress of Extensive Reading, Tokyo, Japan.

Wijaya, K. F. (2018). The role of extensive reading strategy in improving English language education students' vocabulary knowledge in vocabulary class. Proceedings of the Learning English in Modern Era, 6th Undergraduate Conference on ELT, Linguistics and Literature, 216-228. Yogyakarta: Sanata Dharma University Press.

Zacharias, N. T. (2017). Motivating repeated readers in an extensive reading class: A critical reflection on course design. Indonesian Journal of English Language Teaching, 12(2), 149-163. 